\title{
EXPLORING THE RELATIONSHIP BETWEEN LEADERSHIP AND ORGANIZATIONAL INNOVATION
}

\author{
Fathiya Abubaker Mohammed ${ }^{1 *}$ \\ *l Lecturer at the University Sirte in Sirte (Libya).
}

*Corresponding Author: -

\begin{abstract}
: -
In recent years, innovation has become a very important ingredient for competitiveness, productivity and social gain in organizations. Innovation in achieving its goals and objectives depends on the leaders of the organization and their leadership styles. This study aimed to investigate the impact of Managerial Leadership Styles on organizational innovation.

To achieve this aim, a questionnaire was developed and distributed to a sample of 103 subjects in the public banks in Sirte. Data was analyzed using SPSS. In order to test the hypotheses of the study, Pearson's Correlation coefficients were used to determine the direction and strength of the relationship between independent variables and dependent variable.

Two types of leadership styles, namely, autocratic and democratic were found to have direct relationship with the organizational innovation. The results show existence a different leadership styles in these banks, and the impact of democratic style was strongly positive to the organizational innovation. The autocratic style showed negative impact. This implies that democratic leadership is deemed suitable for organizational innovation in the government Banks under study. Implications of the findings were discussed further. Based on those results, the researcher recommends reinforcing democratic style, and some corrective procedures should be applied on autocratic.
\end{abstract}

Keywords: Leadership; autocratic; democratic; innovation; organizational innovation 


\section{INTRODUCTION}

Innovation is a topic that is particularly relevant in organizations today as a result of intense competition and fastpaced change occurring throughout the world (Francis \& Bessant, 2005). Studies show that innovation is affected by factors both external to and internal to organizations (Cravens et al., 2002; Schlegelmilch et al., 2003). Organizations having sustainable and strong innovation ability are those that have a better understanding of the general market and the environmental driving forces, and are able to target their innovative efforts more effectively. This includes analysis of technologies, developing customer needs, being aware of the total competitive environment, establishing basic goals of the organization, and understanding existing organizational culture.

More recent research has been centered on the social implications of innovation. Research from authors like Walther (1994), Howell and Higgins (1990a, 1990b, 1990c), and Rice (1987) suggests that the act of innovating has definite social implications in the personal, organizational, and global context. Given the current social influence direction of modern leadership, it seems reasonable that innovation may be related to transformational leadership qualities (Gumusluoglu \& Ilsev, 2007; Jung, Chow\& Wu, 2003).

The concept of leadership encompasses an extensive range of different interpretations regarding the characteristics of the leaders, their behavior, and their effect on employees and their activities (Howell \& Boies, 2004; Safty, 2003). Leaders are categorized by different criteria and one of them is the leadership style. Examining characteristics of leaders and employees can help in better organization of work, which can help enhance innovation.

\section{Leadership styles}

Autocratic leadership is an extreme form of transactional leadership. Leaders have absolute power over their employees, and the latter have little opportunity to make suggestions, even if it would be in the organization's best interest (Chemers, 2002; Chen \& Bliese, 2002). Autocratic leadership often leads to high levels of absenteeism and employee turnover. However, it could remain effective for some routine and unskilled jobs, as the advantages of control may outweigh the disadvantages.

Democratic leader is a very open and collegial style of running a team (Ray \& Ray, 2012) .This leadership style tends to invite other members of the team to contribute to the decision-making process, although they make the final decision (Jr, 2011). Hence, it helps to develop people's skills. Employees would also feel in control of their own destiny, and motivated to work hard by more than just a financial reward. This approach could however take longer, but often with a better end result. Democratic or participative leadership is most suitable when working as a team is essential, and when quality is more important than speed to market or productivity (Denhardt \& Denhardt, 2003; Warrick, D. 1981).

\subsection{Research studies on leadership style and organizational innovation}

Although much is written about the innovation, relatively little addresses the influence of leadership on the design and implementation of innovation ( Riaz, 2012; Denti, 2011; Shelley \& Perry-Smoth, 2000; Sternberg, 1999; Williams \& Young, 1999). Few researchers address the link between innovation and leadership, and even fewer have explored the relationship between leadership styles and organizational innovation. Gumusluoglu \& Ilsev (2007) examined the effects of leadership style on organizational innovation. They found a significant positive relationship between transformational leadership and creativity. They also determined that transformational leadership had a significant effect on organizational innovation. Alshagh (2003) stated that leadership style plays a vital role in influencing organizational innovation. Some researchers discovered that different leadership styles will engender different working environment and directly affect the innovation (Golla, 2012; Rose, 2014). Bass (1985) proposed that democratic leadership might intrinsically foster more innovation, given its ability to intellectual stimulation. Mousavi, Heidary \& Pour )2011), confirm the theoretical underpinnings of the research in which leadership style acts as a facilitator and stimulator of the direct and indirect effects on people's creativity .

Consistent with the objectives of the study, three hypotheses were developed for testing:

H1: There is relationship between democratic leadership style and organizational innovation. H2: There is relationship between autocratic leadership style and organizational innovation.

\section{Research Design}

Data was collected through survey questionnaires from targeted employees working in public banks in Sirte namely: National commercial Bank, Bank of commerce and Development, Republic Bank, Unity Bank, Bank of North Africa. The respondents included employees from different levels in the banks under study such as lower level of management, middle level of management and top level of management. A total of 150 questionnaires were distributed to selected public banks using a convenient sampling method. However, only 103 employees responded to survey, resulting in a percent response rate.

The measuring instrument for data collection from the employees is in the form of questionnaires which consists of close-ended questions and is divided into three sections. Section 1 consists of 5 items measuring the demographic characteristics of respondents. Section 2 consists of 11 items, with a five point Likert scale, which determined the score of participants related to the two styles of leadership - autocratic and democratic. Section 3 consists of 7 items measuring organizational innovation.

Data was analyzed using SPSS. In this study, independent variables are divided into two types of leadership styles namely, democratic and autocratic. In this study, organizational innovation was as dependent variable. In order to test the hypotheses of the study, Pearson's Correlation coefficients were used to determine the direction and strength of the relationship between independent variables and dependent variables (Chin-Loy \& Mujtaba, 2007; Schimmoeller, 
2007; Zheng, 2009).

Reliability Score for the Research Instruments

In the current study Cronbach's alpha was used to determine the reliability of scales used in the questionnaire (Sekaran, 2000; Spiliotopoulou, 2009; Cooper \& Schindler, 2006). SPSS 16 was used to compute Cronbach's alpha for the elevenitem leadership styles scale and the seven-item organizational innovation scale. This study confirmed a high reliability coefficient for each leadership styles and organizational innovation, as can be seen in Table 3.3 and Table 3.4.

Table 3-3: Cronbach's Alpha for independent and dependent variables

\begin{tabular}{|l|l|l|}
\hline \multicolumn{3}{|c|}{ Cronbach's Al } \\
\hline Leadership styles & 0.71 & 11 Item \\
\hline organizational innovation & 0.83 & 7 Items \\
\hline
\end{tabular}

\section{Results}

Results of testing the first hypothesis using Pearson product-moment coefficient of correlation were: $r=0.58$, $\mathrm{p}<.001$. The null hypothesis was rejected and the alternate hypothesis was supported. The result in Table 2 indicates that there is a statistically significant strong positive correlation between democratic leadership and organizational innovation, which means that the two variables change in the same direction. Autocratic leadership is expected to have a negative effect on the frequency of organizational innovation compared to other leadership styles.

Table 2: Correlations between Democratic Leadership Style and Organizational Innovation

\begin{tabular}{|l|l|l|c|}
\hline \multirow{2}{*}{ Leadership Style } & \multicolumn{3}{|c|}{ Organizational Innovation } \\
\cline { 2 - 4 } & $\begin{array}{c}\text { Pearson } \\
\text { coefficie }\end{array}$ & P-value & Correlation Decision \\
\hline $\begin{array}{l}\text { Democratic } \\
\text { Leadership }\end{array}$ & $0.58^{* *}$ & $<.001$ & H2 was supported \\
\hline
\end{tabular}

Results of testing the second hypothesis using Pearson product-moment coefficient of correlation were: $r=0.43, \mathrm{p}<.001$. The null hypothesis was rejected and the alternate hypothesis was supported. The result in Table 3 indicates that there is a statistically significant positive correlation between autocratic leadership style and organizational innovation, which means that the two variables change in the same direction.

Table 3: Correlations between Autocratic Leadership Style and Organizational Innovation

\begin{tabular}{|c|c|c|c|c|}
\hline \multirow[b]{2}{*}{ Leadership Style } & \multicolumn{4}{|c|}{ Organizational Innovation } \\
\hline & Pearson coefficie & $\mathrm{n}$ & $\mathrm{P}$-value & Correlation Decision \\
\hline Loose Leadership & $0.43^{* *}$ & & $<.001$ & H3 was supported \\
\hline
\end{tabular}

\section{Discussion and Implications}

Our most notable finding regarding innovation centers on the relationship between leadership style and organizational innovation. These results demonstrate a strong relationship between democratic leadership style and organizational innovation. In addition, autocratic leadership style was significantly related to organizational innovation. Innovation in organizations is affected by a wide variety of factors; the most influential factor is leadership style in which democratic and autocratic leadership has found to be significantly correlated with the organizational innovation in the organizations. This leadership style is not considered very effective as the Full Range Leadership Theory also explains that these leaders are delayed in action and decision making, are not attentive, they ignore the leadership responsibilities, and are not very receptive toward others (Bass \& Avolio, 2000; Bass, 1998). These findings are significant and provide basis for further theorization on the relationship between leadership style and organizational innovation.

Since leadership style is the basic determinant of organizational effectiveness and has an impact on the working environment as well as on the employees working on it, and therefore on their innovation levels, it is useful for leaders in the public banks under study to understand both the concepts of leadership style and of organizational innovation. With such an understanding, they would be able to determine the level of a relationship between leadership style and organizational innovation and to develop a strategy that would support innovative programs. First, one managerial implication is that any type of organizational innovation to be adapted in an organization should be evaluated in relation to the style of leadership that exists in the organization. In other words, managers may need to recognize the dominant leadership style in an organization first, and then adopt one or several approaches to implement innovations in the organization that are congruent with the existing style. This poses a genuine challenge to managers in adopting innovations considering the rapid development taking place in external environments. Based on the findings of this study, it can be concluded that leadership style has a positive relationship with the frequency of organizational innovation. 
Successful adaptation requires insight into the implications of these challenges for their organizational strategies. Therefore, the question arises of whether the leaders in these banks should pay attention to the leadership style and organizational innovation when building organizational strategies, given the role of leadership style in the success of these strategies. Further, by evaluating the compatibility between the existing leadership style and organizational innovation, leaders may determine the extent to which the reshaping of the organizational culture may support new organizational innovation activities. By developing cultures that promote innovation, managers of these service institutions can help their institutions become more responsive to the changes in the external environment and thereby become more innovative.

Overall, the findings show that leaders need to understand the different

effects of leadership style on organizational innovation and eradicate negative influences, while strengthening and supporting positive aspects. In addition, leaders should take advantage of the experiences of others in ways that support the process of innovation.

\section{Conclusion and Recommendations}

The study was aimed to find the relationship between leadership style and organizational innovation among the employees from public banks in Sirte - Libya. The main objective of the study was to find out the relationship between leadership style and organizational innovation. For this purpose, the questionnaire was developed; there were 19 variables in all. All questions were close ended. It was administered to 103 employees from public banks in Sirte of Libya. The data was analyzed through SPSS and the findings, conclusion and recommendations are given below.

The study will help us to find out the impact of leadership style on the working and output of employees and their innovative in the organizations. Democratic leadership style has a positive impact on organizational innovation. However the autocratic leadership style produced a negative correlation with organizational innovation. Further, Schein (2004) has highlighted the importance of organizational leaders in shaping the innovation culture of the organizations. Contributions to the theoretical framework of leadership and management theory suggest the importance of leaders in public institutions, such as banks (Handy, 1996). Therefore, there is a need for leaders of selected banks in Libya to modify the leadership style of their organization to create an environment that will promote innovation.

\section{References}

[1].Agbor, E. (2008). Creativity and Innovation: The Leadership Dynamics, Journal of Strategic Leadership, Vol. 1 Iss. 1 , pp. 39-45.

[2].DuPont, B. D. (2002). Leadership-An organization's biggest competitive advantage. University of Calgary Enbridge Inc.

[3].Le Storti, A., "Leadership for innovation: What leaders must do for innovation to happen" Current Issues in Technology Management, Vol. 10, No. 2, Fall 2006.

[4].Ekvall, G. \& Ryhammer, L. (1998). Leadership Style, Social Climate And Organizational Outcomes: A Study of a Swedish University College. Creativity and Innovation Management, 7, 126-130.

[5].Isaksen, S. G. \& Akkermans, H.. J. (2011) Creative Climate: A Leadership Lever for Innovation. "Journal of Creative Behavior", Vol. 45, No.3, p. 161-187.

[6].Barsh, J., Capozzi, M. M., \& Davidson, J. (2008). Leadership and innovation. The McKinsey Quarterly, 1, 37-47.

[7].Bossink, B. A. (2007). Leadership for sustainable innovation. International Journal of Technology Management and Sustainable Development, 6, 135-149.

[8].Byrne, C. L., Mumford, M. D., Barrett, J. D., \& Vessey, W. B. (2009). Examining the leaders of creative efforts: What do they do, and what do they think about? Creativity and Innovation Management, 18, 256-268.

[9].Elenkov, D. S., \& Manev, I. M. (2009). Senior expatriate leadership's effects on innovation and the role of cultural intelligence. Journal of World Business, 44, 357-369.

[10]. Gumusluoglu, L., \& Ilsev, A. (2007). Transformational leadership, creativity, and organizational innovation. Journal of Business Research, 62, 461-473.

[11]. Jung, D. I., Chow, C., \& Wu, A. (2003). The role of transformational leadership in enhancing organizational innovation: Hypotheses and some preliminary findings. The Leadership Quarterly, 14, 525-544.

[12]. Mathisen, G. E., Mykletun, R. J., \& Einarsen, S. (2007). The relationships between leader creativity, work climate and organizational creativity. Paper presented at the European association for creativity and innovation conference, Copenhagen, Denmark.

[13]. Safty, A.(2003). Value Leadership. University of Bahçesehir/Istanbul.

[14]. Lussier, R., \& Achua, C. (2010). Leadership: Theory, application and skill development. Mason: South-Western Publications.

[15]. Kippenberger, T. (2002). Leadership styles. Oxford: Capstone Publishing

[16]. Chemers, M. M. (2002). Efficacy and effectiveness: Integrating models of leadership and intelligence. In R. E. Riggio \& S. E. Murphy (Eds.), Multiple intelligences and leadership (pp. 139-160). Mahwah, NJ: Erlbaum.

[17]. Chen, G., \& Bliese, P. D. (2002). The role of different levels of leadership in predicting self- and collective efficacy: Evidence for discontinuity. Journal of Applied Psychology, 87(3), 549-556.

[18]. Warrick, D. (1981). Leadership Styles and Their Consequences. Journal of Experirntial Learning and Simulation. 3 , 4. P.155-172.

[19]. Northouse, P. G. 2010. Leadership, theory and practice (5th ed.). Sage, Thousand Oaks, CA.

[20]. Yukl, G. A. 2005. Leadership in organizations (6th ed.). Upper Saddle River, NJ: Prentice-Hall. 
[21]. Davis, J. 2003. Learning to lead. Westport, CT: American Council on Education/Praeger.

[22]. Spears, L. C., \& Lawrenece, M. 2003. Focus on Leadership: Servant-leadership for the Twenty first Century. San Francisco:

[23]. Hirtz, P. D., Murray, S. L., \& Riordan, C. A. 2007. The effects of leadership on quality. Engineering Management Journal, Vol.19, No. 1, pp. 22-27.

[24]. House, R., Hanges, P., Javidan, M., Dorfman, P., \& Gupta, V. 2004. Culture, leadership and organizations. Beverly hills, CL: Sage Publications Inc.

[25]. Denhardt, J. V., \& Denhardt, R. B. (2003). The new public service: Serving, not steering,Armonk, NY: M. E. Sharpe.

[26]. Mousavi, S. H., Heidary, A., \& Pour F. K. (2011). The relationship between leadership styles and physical education teachers 'creativity. International Journal of Academic Research in Business and Social Sciences, 1(3), 82-84.

[27]. Bhatti.N., Maitlo. G.M., Shaikh. N., Hashmi. M. A, Shaikh. F. M. (2012). The Impact of Autocratic and Democratic Leadership Style on Job Satisfaction. Journal of International Business Research, Vol. 5, No. 2, P, 192-102.

[28]. Golla, E., J. (2012). The Relationship between Transformational and Transactional Leadership Styles and Innovation

[29]. Commitment and Output at Commercial Software Companies, The Dissertation of Doctor's Degree, Business Administration, University Of Phoenix, United States.

[30]. Ray, S., \& Ray, I., A. 2012. Understanding Democratic Leadership: Some Key Issues And Perception With Reference To India's Freedom Movement. Afro Asian Journal of Social Sciences, Vol. 3, No. 3. ISSN: 2229 - 5313.

[31]. Rose, M., M. (2014). The Relationship between The Full Range of Leadership Theory and Research and Development

[32]. Team Climate For Innovation, The Dissertation of Doctor's Degree of Philosophy, University Of Capella, United States. Pr 